\title{
FAUNAL ANALYSIS AND INJURIES CHARACTERIZATION OF Polistinae (Hymenoptera, Vespidae) IN NIAGARA ROSADA VINEYARDS IN BENTO GONÇALVES, RIO GRANDE DO SUL STATE, BRAZIL
}

\author{
ANÁLISE FAUNÍSTICA E CARACTERIZAÇÃO DE INJÚRIAS DE Polistinae \\ (Hymenoptera, Vespidae) EM PARREIRAIS DE NIAGARA ROSADA EM BENTO \\ GONÇALVES, RIO GRANDE DO SUL, BRASIL
}

\section{Ida Maria de OLIVEIRA ${ }^{\mathbf{1}}$; Alci Enimar LOECK ${ }^{\mathbf{1}}$; Flávio Roberto Mello GARCIA ${ }^{\mathbf{1}}$; Marcos BOTTON ${ }^{2}$}

1. Programa de Pós-Graduação em Entomologia, Instituto de Biologia, Universidade Federal de Pelotas, Pelotas, RS, Brasil. flavio.garcia@ufpel.edu.br; 2. Laboratório de Entomologia, Embrapa Uva e Vinho, Bento Gonçalves, RS, Brazil.

\begin{abstract}
The State of Rio Grande do Sul is a major producer of grapes in Brazil, highlighting the Serra Gaúcha as the main producing region. In the pursuit of good quality in grapes it is essential the control of pests, especially insects. This study highlights the incidence of wasps, which cause serious damage at harvest time. This study aimed to characterize the community of social wasps (Hymenoptera, Vespidae) through faunal analysis and to examine the relationship of these insects with injuries to the grape berries in vineyards of Bento Gonçalves, Rio Grande do Sul State. Therefore, active search were made in January and February 2014, followed by analysis of frequency, constancy, abundance, dominance and diversity. Ten species of wasps were able to use grape berries as food. The two dominant species were Polybia ignobilis and P. minarum, however, Synoeca cyanea has greater ability to break the intact berries. Other three species, Polistes cavapytiformis, $P$. versicolor and Brachygastra lecheguana, were also able to break the skin of grapes, but of damaged berries.
\end{abstract}

KEYWORDS: Serra Gaúcha. Social wasp. Grape. Damage. Wine.

\section{INTRODUCTION}

Wasps are insects found in many environments such as native, agricultural and urban areas, with diverse foraging behavior as well as ecological and economic importance (WESTEBERHARD et al., 1995).The family Vespidae is composed of six monophyletic subfamilies, three of these occur in South America. Two subfamilies are made up of solitary wasps, Masarinae and Eumeninae, and one subfamily consists of social species, the subfamily Polistinae (CARPENTER; MARQUES, 2001).

Adult social wasps feed on liquids, nectar, honey, and other sugary products, cell content and water (CARPENTER; MARQUES, 2001). However, larvae are fed with protein diet from small insects trapped and macerated by adult wasps; this interaction has relevance in the biological control of pests (CARPENTER; MARQUES, 2001; PREZOTO; 2007).

In vineyard cultivation, one of the points of increasing importance relates to the sanity of berries especially at harvest time, essential to develop quality products (SILVEIRA, 2011). However, a number of harmful species have been frequently reported causing damage to berries (OLIVEIRA et al., 2012; BOTTON et al., 2012). A group of social insects have been reported frequently as harmful to the crop, and its attack is usually associated with the presence of bees (HICKEL; SCHUCK, 1995). Wasps are considered beneficial insects acting, for example, in the control of other insects, some agricultural pests (PREZOTO et al., 2006; ELISEI et al., 2010; PICANÇO et al., 2011; PREZOTO; BRAGA, 2013), and integrating the guild of pollinators (BARROS, 1998; SÜHS et al., 2009), but during the summer they can found a rich source of food in maturing grapes.

The collection of carbohydrates is the main activity of wasp colonies (RESENDE et al., 2001; CANEVAZZI; NOLL, 2011). Hickel and Schuck (1995) observed, in the Santa Catarina State, the attack of these insects to bunches of grapes, leading to the rupture of the skin and damage to the fruit. In this study, Synoeca cyanea (Fabricius, 1775) was present at high frequency in crops, with the behavior of breaking the skin of the fruit. Besides, in Brazil, there is information on the use of pitanga fruit (SOUZA et al., 2013), cashew (SANTOS; PRESLEY, 2010) and mango (BARBOSA et al., 2014) by different species of wasps.

Among the different grape varieties, Niagara Rosada is less susceptible to fungal diseases 
and generates lower production costs, thus it represents an interesting alternative to the small producer (MAIA; CAMARGO, 2012). This grape is highly appreciated by the Brazilian consumer, intended mostly for fresh consumption, its cultivation has expanded rapidly in the states of São Paulo, Santa Catarina, Rio Grande do Sul and Minas Gerais (MAIA; CAMARGO, 2012).

In this regard, this study aimed to identify the species of Polistinae (Hymenoptera, Vespidae) in Niagara Rosada vineyards in the municipality of Bento Gonçalves, Rio Grande do Sul State, and to perform a faunal analysis with the assemblage found and to determine the relationship of insects with injuries to fruit.

\section{MATERIAL AND METHODS}

Active search was conducted by means of visual and spatial exploration to collect the target species during the months of January and February 2014, in vineyards of the grape variety Niagara Rosada (Vitis labrusca L.), in rural properties in the municipality of Bento Gonçalves, Serra Gaúcha, northeastern Rio Grande do Sul State. Three areas were delimited in the municipality, in a pergola trellis system, located at different sites. The first was held at Embrapa Grape and Wine (2909'49,47"S, $\left.51^{\circ} 31^{\prime} 42,95^{\prime \prime} \mathrm{W}\right)$; the second in Tuiuti District in the Linha de Mari (29 $\left.02^{\prime} 54,49^{\prime \prime S}, 51^{\circ} 38^{\prime} 03,97^{\prime \prime} \mathrm{W}\right)$; and the third at the Vale dos Vinhedos $\left(29^{\circ} 12^{\prime} 01,27^{\prime \prime} \mathrm{S}\right.$, $\left.51^{\circ} 33^{\prime} 02,61^{\prime \prime W}\right)$. Samples were taken in the maturation/pre-harvest period of grapes, because this is the period of occurence of damage in grapes caused by wasps, determining six consecutive days of collection for each vineyard. The collections were performed in the morning and early afternoon period, a period in which the wasps focus their search for carbohydrates resources (RESENDE et al., 2001; ELISEI et al., 2005; ELISEI et al., 2013), totalizing six hours of collection a day and equal sampling effort in all area.

Specimens were collected with entomological net and collector bottles, randomly. In each area, we spent a sampling effort of 36 hours, with collections focused on the wasps that were on the berries. The active collection provides a complete sampling of wealth and obtaining knowledge of the habits and behavior of the species collected when they are little known or unknown in literature, or to compare areas of study (TEIXEIRA, 2012). The insects collected were identified based on external morphological characters, using identification keys proposed by Richards (1978), Carpenter and Marques (2001) and Hermes and Köhler (2004).

For the purpose of characterization of the assemblages, we analyzed frequency, constancy, abundance, dominance, richness, evenness and Shannon-Weiner diversity index ( $\left.H^{\prime}\right)$. The faunal analyses were performed from the number of records for each species in each area. For the calculations of abundance, constancy, frequency and dominance, we used presence/absence data (LONGINO, 2000; LUTINSKI et al., 2008). We selected this method since the social characteristics of wasps can affect these analyses when performed on the absolute numbers of specimens collected, due to the variation in the number of insects in the composition of the colonies (ANDENA; CARPENTER, 2014), and can affect the analyses obtained for these species (SANTOS et al., 2007; SOUZA et al., 2014).

During the collection of wasps in the vineyards, video records were taken in order to record the species of wasps and the dynamics of damage to grapes. To this end, we used a video camera Sony® full HD-HDR PJ380 and a tripod support in a spot of vineyard and every hour, approximately, it was checked and replaced the shooting point. Images were subsequently analyzed in order to associate the presence of species with possible rupture of the berries.

\section{RESULTS AND DISCUSSION}

During the sampling period, we captured 634 wasps of the subfamily Polistinae (Table 1), belonging to ten species: Polistes versicolor (Olivier 1791), Polistes cavapytiformis Richards 1978, Brachygastra lecheguana (Latreille 1824), Polybia sericea (Olivier 1791), Polybia ignobilis (Haliday 1836), Polybia scutellaris (White 1841), Polybia minarum Ducke 1906, Synoeca cyanea (Fabricius 1775), Agelaia multipicta Haliday 1836 and Polybia fastiosuscula Saussure 1854. The genus Polybia was predominant in samples in relation to the other species caught.

Among the areas chosen for sampling, the vineyard of Embrapa showed the highest richness ( $\mathrm{S}$ $=10$ species $)$, followed by Linha de Mari $(S=8$ species) and Vale dos Vinhedos ( $\mathrm{S}=7$ species) (Table 1). In the three sites, there was alternating occurrence between these species, none of which was found exclusively in one region. 
Table 1. Faunal analysis of wasp species sampled in vineyards in the municipality of Bento Gonçalves, Sate of Rio Grande do Sul, during the months of January and February 2014.

\begin{tabular}{llllllllllllllllll}
\hline & \multicolumn{1}{c}{ EMBRAPA } & \multicolumn{1}{c}{ Linha de Mari } & \multicolumn{4}{c}{ Vale dos Vinhedos } \\
\hline Species & n & A & C & D & F & n & A & C & D & F & n & A & C & D & F \\
Agelaia multipicta & 1 & R & Z & ND & PF & 65 & A & W & D & F & 9 & A & W & D & F \\
Brachygastra lecheguana & 2 & R & Z & ND & PF & 4 & C & W & ND & F & 0 & - & - & - & - \\
Polistes cavapytiformis & 68 & A & W & D & MF & 0 & - & - & - & - & 5 & A & W & D & F \\
Polistes versicolor & 2 & R & Z & ND & PF & 39 & A & W & D & F & 1 & D & Z & ND & F \\
Polybia fastiosuscula & 4 & C & W & ND & F & 7 & C & W & ND & F & 0 & - & - & - & - \\
Polybia ignobilis & 121 & A & W & D & MF & 37 & A & W & D & F & 15 & MA & W & D & MF \\
Polybia minarum & 9 & A & W & D & MF & 23 & A & W & D & F & 67 & MA & W & D & MF \\
Polybia scutellaris & 21 & C & W & ND & F & 0 & D & Z & ND & PF & 6 & - & - & - & - \\
Polybia sericea & 4 & A & W & D & MF & 1 & - & - & - & - & 0 & C & W & ND & F \\
Synoeca cyanea & 3 & C & Z & ND & F & 50 & A & W & D & F & 1 & D & Z & ND & F \\
Richness (S) & 10 & & & & & 8 & & & & 7 & & & & \\
Diversity (H') & 1.34 & & & & 1.72 & & & & 1.17 & & & \\
Evenness (E) & 0.58 & & & & 0.83 & & & & 0.60 & & & \\
\hline
\end{tabular}

$\mathrm{A}=$ Abundance; $\mathrm{ma}=$ very abundant $\mathrm{a}=$ abundant $\mathrm{c}=$ common; $\mathrm{di}=$ dispersed $; \mathrm{r}=$ rare $\mathrm{C}=$ Constancy: $\mathrm{w}=$ constant $\mathrm{y}=\mathrm{accessory} ; \mathrm{z}$ $=$ accidental; $\mathrm{D}=$ Dominance: $\mathrm{d}=$ dominant; $\mathrm{nd}=$ non dominant $\mathrm{F}=$ Frequency; $\mathrm{mf}=$ very frequent; $\mathrm{f}=$ frequent; $\mathrm{pf}=$ infrequent; $=$ absent., $\mathrm{n}=$ number of individuals

This variation was probably because some species of wasps are established only in the presence of specific substrates, and nesting is speciesspecific, in other words, each species uses different materials, methods of construction of nests and architectures (DEJEAN et al., 1998; SANTOS; GOBBI, 1998; SANTOS et al., 2009). A species of wasp may have a preference for different nesting substrates according to physical and/or biological characteristics of the environment (SANTOS; GOBBI, 1998).

The site with the highest diversity $\left(\mathrm{H}^{\prime}=\right.$ 1.72) was the vineyard located in the Linha de Mari (Table 1). All areas have natural vegetation nearby, capable of holding nests. However, of the evaluated areas, this is the one with the lowest human influence, and with sources of water in the surroundings. According to Santos et al. (2009), the maintenance of these areas with natural vegetation allows the coexistence of a greater diversity of species.

The diversity indices obtained herein can be considered low, mainly in the area of Embrapa, where there was no uniformity of individuals of the species collected. Probably this was the cause of the low value, since the diversity index increases with a larger value of evenness. In other words, the Shannon index takes into account the uniformity of the species abundance (MARGALEF, 1972).

$P$. ignobilis and $P$. minarum were abundant, constant, dominant and very frequent in the areas of
Embrapa and Vale dos Vinhedos, and frequent in Linha de Mari. These species were considered dominant as they stood out with higher faunal indices (Table 1) (SILVEIRA NETO et al., 1995).

The other species, $P$. versicolor, $P$. cavapytiformis, $B$. lecheguana, $P$. sericea, $P$. scutellaris, $S$. cyanea, A. multipicta and $P$. fastiosuscula, had a high variation according to the area sampled. The wasp $S$. cyanea was not constant, but was frequent in the sampling, with abundance ranging from common, abundant and dispersed in the three different sampling areas (Table 1).

Hickel and Schück (1995) described the occurrence of six species of wasps in vineyards in the municipality of Videira, Santa Catarina State; three of these species occurring also in the vineyards of Bento Gonçalves: P. ignobilis, P. scutellaris and S. cyanea.

Some species have also been recorded feeding on other fruits. Nine species were observed feeding on ripe fruits of Myrciaria sp. A. multipicta and $B$. lecheguana were identified at low frequency; $P$. ignobilis at medium frequency; whereas $P$. sericea and $S$. cyanea at high frequencies (SOUZA et al., 2009). Damage to Psidium sp. and Mangifera indica were also recorded for $S$. cyanea (BRUGGER et al., 2011; BARBOSA et al., 2014).

For $P$. minarum, there is no record of fruit damage, being the second most captured species, in addition it is very common in the region of Serra Geral (HERMES; KÖHLER, 2004) and rare in 
studies in other regions of the Rio Grande do Sul State (LUZ et al., 2014).

Field observations while shooting indicated that $S$. cyanea, $P$. cavapytiformis, $P$. versicolor and $B$. lecheguana have ability to break berries (https://youtu.be/X852DOg3OvQ). The species $S$. cyanea is better able to perform such injury, given its mandibular robustness. $P$. cavapytiformis, $P$. versicolor and B. lecheguana also broke the berries with some physiological or phytosanitary deficiency. The other species were not found breaking the berries, but feeding on the leaked juice. A. multipicta was also recorded feeding on fallen fruit, on the ground.

There are anatomical and physiological differences between the varieties of grapes, such as size, cell turgor and extensibility and plasticity of cell wall and these factors along with environmental conditions are responsible for the splits and cracks in the berries (DOKOOZLIAN, 2000). Variation in berry volume combined with its thin skin is an important factor that can lead to cracks in grapes (BORGES et al., 2012).

The occurrence of frugivorous birds in commercial vineyards also propitiates insect attack. These birds cause direct damage to grapes and the juice spilled by breaking the berry attracts insects, including wasps and bees (BOTTON et al., 2012). The combination of these factors creates attractive conditions and allows the damage caused by wasps in the vineyards.

Food ambiguity places wasps in important position in the trophic balance of communities.
Besides being pollinators, several species of social wasps are responsible for the control of arthropods. $B$. lecheguana, $P$. ignobilis, $P$. scutellaris, $P$. sericea, $P$. fastidiosuscula, $P$. versicolor and $S$. cyanea are examples of predators of lepidopteran pests (PICANÇO et al., 2011; ELISEI et al., 2010; MACHADO et al., 1988; PREZOTO et al., 2006).

Social wasps seek different food resources, such as animal protein, water, carbohydrates and material for construction and maintenance of nests. Carbohydrate is important not only for the larvae, but is also a source of energy for adults (RICHTER, 2000). The choice of a food source is related to nest behavior, smells and visual information. And the choice of food is influenced by the presence of other visitors (RICHTER, 2000; HRNCIR et al., 2007). Thus, the occurrence of a wasp on the bunch attracts more specimens to the site, increasing the damage.

\section{CONCLUSIONS}

Injuries to berries in vineyards in the municipality of Bento Gonçalves are related to 10 species, including the most abundant $P$. ignobilis and P. minarum.

S. cyanea has greater ability to cause injuries to intact grape berries and $P$. cavapytiformis, $P$. versicolor and B. lecheguana are able to break berries damaged by fungi or under water stress. The remaining species feed on damaged berries and leaked juice.

RESUMO: O Rio Grande do Sul é o maior produtor de uvas no Brasil, destacando-se a Serra Gaúcha como principal região produtora. Na busca de qualidade das uvas é fundamental o controle de pragas, especialmente insetos. Este trabalho identifica a incidência de vespas que acarretam graves danos na época de colheita. A pesquisa foi conduzida com o objetivo caracterizar a assembleia de vespas sociais (Hymenoptera, Vespidae) através de análise faunística e a relação destas com injúrias as bagas, em parreirais do município de Bento Gonçalves, Rio Grande do Sul. Para tanto, foram realizadas coletas ativas nos meses de janeiro e fevereiro de 2014, realizando-se análise de frequência, constância, abundância, dominância e diversidade da comunidade. Foram identificadas 10 espécies de vespas capazes de utilizar as bagas de uva como alimento. As espécies predominantes foram Polybia ignobilis e P. minarum, todavia, Synoeca cyanea apresenta maior capacidade de rompimento de bagas íntegras. P. cavapytiformis, P. versicolor e Brachygastra lecheguana também foram capazes de abrir a casca dos frutos em bagas anteriormente danificadas.

PALAVRAS-CHAVE: Serra Gaúcha. Vespa social. Uva. Danos. Vinho.

\section{REFERENCES}

ANDENA, S. R.; CARPENTER, J. M. Checklist das espécies de Polistinae (Hymenoptera, Vespidae) do semiárido brasileiro. In: BRAVO, F.; CALOR, A. (Org.). Artrópodes do Semiárido: biodiversidade e conservação. Feira de Santana: Printmidia, 2014. p. 169-180. 
BARBOSA, B. C.; PASCHOALINI, M. F.; PREZOTO, F. Temporal activity patterns and foraging behavior by social wasps (Hymenoptera, Polistinae) on fruits of Mangifera indica L. (Anacardiaceae). Sociobiology, v. 61, n. 2, p. 239-242, 2014.

BARROS, M. G. Sistemas reprodutivos e polinização em espécies simpátricas de Erythroxylum P. Br. (Erythroxylaceae) do Brasil. Revista Brasileira de Botânica, v. 21, n.2, p.159-166, 1998.

BORGES, R.S.; ROBERTO, S. R.; YAMASHITA, F.; OLIVATO, J.B.; ASSIS, A.M. Sensibilidade ao rachamento de bagas das videiras 'Concord', 'Isabel' e 'BRS Rúbea'. Revista Brasileira de Fruticultura, v. 34, n. 3, p. 814-822. 2012.

BOTTON, M.; MAIA, J.D.G.; SPECHT, A.; MACHOTA Jr, R.; ZENKER, M.M. Pragas da uva Niágara no Brasil. In: MAIA, J.D.G.; CAMARGO, U.A. (Org.). O cultivo da videira Niágara no Brasil. Brasília: Embrapa Informação Tecnológica, 2012. p. 229-251.

BRUGGER, B. P.; SOUZA, L. S. A. de; SOUZA, A. R. de; PREZOTO, F. Social wasps (Synoeca cyanea) damaging Psidium sp. (Myrtaceae) fruits in Minas Gerais State, Brazil. Sociobiology, v. 57, n.3, p. 533-536, 2011.

CANEVAZZI, N. C. S.; NOLL, F. B. Environmental factors influencing foraging activity in the social wasp Polybia paulista (Hymenoptera: Vespidae: Epiponini). Psyche, v. 2011, article ID 542487, doi:10.1155/2011/542487.

CARPENTER, J. M.; MARQUES, O.M. Contribuição ao estudo dos vespídeos do Brasil (Insecta, Hymenoptera, Vespoidea, Vespidae). Cruz das Almas: Universidade Federal da Bahia, Escola de Agronomia, Série Publicações Digitais, 2001. CD-ROM.

DEJEAN, A.; CORBARA, B.; CARPENTER, J.M. Nesting site selection by wasps in the Guianese rain forest. Insectes Sociaux, v. 45, n.1, p. 33-41, 1998.

DOKOOZLIAN, N.K. Grape berry growth and development. In: CHRISTIANSEN, L.P. Raisin Production Manual. University of California - Oakland: Agricultural and Natural Resources Publication, 2000. p. 30-37.

ELISEI, T.; RIBEIRO JUNIOR, C.; GUIMARÃES, D. L.; PREZOTO, F. Foraging Activity and Nesting of Swarm-Founding Wasp Synoeca cyanea (Hymenoptera: Vespidae, Polistinae). Sociobiology, v. 46, n. 2, 2005.

ELISEI, T.; NUNES, J. V.; RIBEIRO JUNIOR, C.; FERNANDES JUNIOR, A.J.; PREZOTO, F. Uso da vespa social Polistes versicolor no controle de desfolhadores de eucalipto. Pesquisa Agropecuária Brasileira, v. 45, p. $958-964,2010$.

ELISEI, T.; NUNES, J..; RIBEIRO JUNIOR, C.; FERNANDES JUNIOR, A.; PREZOTO, F. What is the ideal weather for social wasp Polistes versicolor (Olivier) go to forage? EntomoBrasilis, v.6, n. 3, p. 214-216, 2013.

HERMES, M.G.; KÖHLER, A. Chave ilustrada para as espécies de Vespidae (Insecta, Hymenoptera) ocorrentes no cinturão verde de Santa Cruz do Sul, RS, Brasil. Caderno de Pesquisa Série Biologia, v. 16, n. 2, p. 65-115, 2004.

HICKEL, E.R.; SCHUCK, E. Vespas e abelhas atacando a uva no Alto Vale do Rio do Peixe. Agropecuária Catarinense, v. 8, n. 1, p. 38-40, 1995.

HRNCIR, M.; MATEUS, S.; NASCIMENTO, F.S. Exploitation of carbohydrate food sources in Polybia occidentalis: social cues influence foraging decisions in swarm-founding wasps. Behavioral Ecology and Sociobiology, v. 61, p. 975-983, 2007. 
LONGINO, J. What to do with the data. In: AGOSTI, D.; MAJER, J.D.; ALONSO, L.E.; SCHULTZ, T. R. Ants: standard methods for measuring and monitoring biodiversity. Washington: Smithsonian Institution, 2000. p. 186-203.

LUTINSKI, J.A., GARCIA, F. R. M.; LUTINSKI, C. J., IOP, S. Diversidade de formigas na Floresta Nacional de Chapecó, Santa Catarina, Brasil. Ciência Rural, v. 38, n. 7, p. 1810-1816, 2008. doi: dx.doi.org/10.1590/S0103-84782008000700002.

LUZ, F.A.; ABEIJON, L. M.; GARCIA, F. R. M. Vespas visitantes florais de duas espécies de Eryngium (Apiaceae) no Bioma Pampa, Rio Grande do Sul, Brasil. Revista de Ciências Ambientais, v.8, n. 1, p. 49-55, 2014.

MACHADO, V. L. L.; GOBBI, N.; ALVES JUNIOR, V. V. Material capturado e utilizado na alimentação de Polybia (Trichothorax) sericea (Oliver, 1791) (Hymenoptera, Vespidae). Revista Brasileira de Zoologia, v. 5, n. 2, p. 261-266, 1988.

MAIA, J. D. G; CAMARGO, U. A. (Org.). O cultivo da videira Niágara no Brasil. Brasília: Embrapa Informação Tecnológica, 2012. 301 p.

MARGALEF, R. Homage to Evelyn Hutchinson, or why is an upper limit to diversity. Transactions of the Connecticut Academy of Arts and Sciences, v. 14, p. 211-235, 1972.

OLIVEIRA, J. E. M.; HAJI, F. N. P.; MOREIRA, F. R. B.; PARANHOS, B. A. J. Pragas. In: Lima MF, Moreira FRB (Eds.). Uva de mesa: fitossanidade. Brasília, DF: Embrapa. 111 p. 2012.

PICANÇO, M. C.; BACCI, L.; QUEIROZ, R. B.; SILVA, G. A.; MIRANDA, M. M. M.; LEITE, G. L. D.; SUINAGA, F. A. Social wasps predators of Tuta absoluta. Sociobiology, v. 58, n. 3, p. 621-633, 2011.

PREZOTO, F.; SANTOS-PREZOTO, H. H.; MACHADO, V. L. L.; ZANUNCIO, J. C. Prey captured and used in Polistes versicolor (Olivier) (Hymenoptera: Vespidae) nourishment. Neotropical Entomology, v. 35, n 5, p. 707-709, 2006.

PREZOTO, F. Vespas sociais como agentes de controle biológico de pragas agrícolas. In: Simpósio de Controle Biológico, 10., 2007, Brasília. Anais... Brasília, DF: Embrapa Recursos Genéticos e Biotecnologia, 2007.

PREZOTO, F.; BRAGA, N. Predation of Zaprinus indianus (Diptera: Drosophilidae) by the social wasp Synoeca cyanea (Hymenoptera: Vespidae). Florida Entomologist, v. 96, n. 2, p. 670-672, 2013.

RICHTER, R. M. Social wasp (Hymenoptera: Vespidae) foraging behavior. Annual Reviews Entomology, v. 45, p. 121-150, 2000.

RESENDE, J. J.; SANTOS, G. M. M.; BICHARA FILHO, C. C.; GIMENES, M. Atividade diária de busca de recursos pela vespa social Polybia occidentalis occidentalis (Olivier, 1791) (Hymenoptera, Vespidae). Revista Brasileira de Zoociências, v. 3, n.1, p.105-115, 2001.

RICHARDS, O. W. The social wasps of the Americas (excluding the Vespinae). London: British Museum of Natural History. 580p. 1978.

SANTOS, G. M. M; GOBBI, N. Nesting habitats and colonial productivity of Polistes canadensis canadensis (L.) (Hymenoptera, Vespidae) in a Caatinga area, Bahia State, Brazil. Journal of Advanced Zoology, v. 19, p. 63-69, 1998. 
SANTOS, G. M. M.; BICHARA FILHO C. C.; RESENDE, J. J.; CRUZ, J. D.; MARQUES O. M. Diversity and community structure of social wasps (Hymenoptera: Vespidae) in three ecosystems in Itaparica Island, Bahia State, Brazil. Neotropical Entomology, v. 36, n. 2, p. 180-185, 2007.

SANTOS, G. M. M.; CRUZ, J. D.; MARQUES, O. M.; GOBBI, N. Diversidade de vespas sociais (Hymenoptera: Vespidae) em áreas de Cerrado na Bahia. Neotropical Entomology, v. 38, n. 3, p. 317-320, 2009.

SANTOS, G. M. M; PRESLEY, S. J. Niche overlap and temporal activity patterns of social wasps (Hymenoptera: Vespidae) in a Brazilian cashew orchard. Sociobiology, v. 56, n. 1, p. 121-131, 2010.

SILVEIRA, S. V. Cuidados no vinhedo que antecedem à colheita, para obtenção de uva de qualidade. Série Uvas. Bento Gonçalves: Embrapa Uva e Vinho, 2011.

SILVEIRA NETO, S.; MONTEIRO, R. C.; ZUCCHI, R. A.; MORAES, R. C. B. Uso da análise faunística de insetos na avaliação do impacto ambiental. Scientia Agricola, v. 52, n. 1, p. 9-15, 1995.

SOUZA, A. R.; VENANCIO, D. F. A.; PREZOTO, F. Interaction between social wasps (Hymenoptera: Vespidae: Polistinae) and fruits of Myrciaria sp. (Myrtaceae). In: Congresso Latino Americano de Ecologia, 3. 2009, São Lourenço. Anais... São Lourenço: Sociedade de Ecologia do Brasil, 2009. p.1-3.

SOUZA, G. K.; PIKART, T. G.; JACQUES, G. C.; CASTRO, A. A.; SOUZA, M. M.; SERRÃO, J. E.; ZANUNCIO, J. C. Social wasps on Eugenia uniflora Linnaeus (Myrtaceae) plants in an urban area.

Sociobiology, v. 60, n. 2; p. 204-209, 2013.

SOUZA, M. M.; PIRES, E. P.; PREZOTO, F. Seasonal richness and composition of social wasps (Hymenoptera, Vespidae) in areas of cerrado biome in Barroso, Minas Gerais, Brazil. Bioscience Journal, v. 30, n. 2, p. 539-545, 2014.

SÜHS, R. B.; SOMAVILLA, A.; KÖHLER, A.; PUTZKE, J. Vespídeos (Hymenoptera, Vespidae) vetores de pólen de Schinus terebinthifolius Raddi (Anacardiaceae), Santa Cruz do Sul, RS, Brasil. Revista Brasileira de Biociências, v. 7, n. 2, p. 138-143, 2009.

TEIXEIRA, F. M. Técnicas de captura de Hymenoptera (Insecta). Vértices, v. 14, n.1, p. 169-198, 2012.

WEST-EBERHARD, M. J.; CARPENTER, J. M.; HANSON, P. E. The vespid wasps (Vespidae). In: HANSON, P. E.; GAULD, I. D. (Org.). The Hymenoptera of Costa Rica. Oxford: The Natural History Museum, Oxford University Press, 1995. p. 561-587. 